\title{
PEMBERDAYAAN SEKTOR INFORMAL DALAM UPAYA PENINGKATAN PENDAPATAN MASYARAKAT
}

\author{
Drs. Amir Dedoe, M.Si*
}

\begin{abstract}
This research aims to explain wheater government intervention in the form of capitalization, education, training/skill, and organization estabilishment could form ators of informal sector in increasing their income, and analyze the impact of government intervention on the increase of community income of informal sector.

This research was a case study used a descriptive-qualitative analysis. The data were obtained through observation and in depth interview. The sample was selected using purposive sampling method. Since the actors of informal sector working as sidewalk traders were divided into certain groups, the key informant were also selected purposively. These groups were the sidewalk traders who were not married and that been working for less than five years and the ones who were maried and had been working for more than five years. The data were than processed using qualitative analysis.

The results show that the participation of informant in informal sector activity as sidewalk traders in Sungailiat village is caused by their family's economic condition. The factors affecting the business of sidewalk trades are economic need and limited capital. The prospect of business development of sidewalk traders indicates a positive trend by obtaining capital aid from the local government of Bangka Regency accompanied by forming institution. By such and aid, the sidewalk traders could increase their business volume and develop it by making use of the strengthening of existing institution.
\end{abstract}

\section{Keyword :}

Empowerment and informal sector

\section{PENDAHULUAN}

\subsection{Latar Belakang Masalah}

Di Indonesia, munculnya dilema ekonomi informal adalah sebagai dampak dari makin kuatnya proses modernisasi yang bergerak bias, menuju sifat-sifat yang dualistis. Bias pembangunan secara makro akan menghasilkan sistem ekonomi lain yaitu sektor informal, yang sebagian besar

\footnotetext{
* Penulis adalah Dosen pada Jurusan Sosiologi, Fakultas Ilmu Sosial dan Ilmu Politik, Universitas Bangka Belitung.
}

terjadi di negara-negara sedang berkembang termasuk Indonesia. Fenomena dualisme ekonomi yang melahirkan sektor informal ini menunjukkan bukti adanya keterpisahan secara sistem empiris antara sektor informal dan formal dari sebuah sistem ekonomi nasional. Hal ini sekaligus memberikan legitimasi ekonomi dan politik bahwa perekonomian suatu negara mengalami stagnasi dengan tingkat pengangguran yang sangat tinggi 
dan ketimpangan sosial ekonomi yang cukup besar.

Persoalan yang menyangkut pedagang kaki lima banyak dilihat dari segi kebijaksanaan menata lingkungan fisik perkotaan semata. Kebijaksanaan yang dikeluarkan untuk mengatasi pedagang kakilima di kota-kota besar pada umumnya dan kota kecil temasuk kota Sungailiat pada khususnya eksistensi dari intervensi pemerintah sangat bermakna buat pedagang kakilima atau pekerja sektor informal.

Salah satu penyebab tumbuh suburnya sektor informal di kota Sungailiat yang secara kualitas cukup banyak dan dinamikanya cukup menonjol dalam kesehari-harian. Salah satu penyebab tumbuh suburnya sektor informal di kota Sungailiat adalah terbatasnya kemampuan mengakses pekerjaan pada sektor formal termasuk pinjaman modal bagi pelaku ekonomi kecil dan menengah sebagai bentuk dari intervensi pemerintah serta terbatasnya kemampuan mengeksploitasi sumber daya alam, dan semakin tingginya pertumbuhan serta mobiltas penduduk. Walaupun dalam pengamatan sepintas tidak diperoleh data yang akurat mengenai besarnya jumlah pekerja sektor informal di kota Sungailiat, karena tidak adanya data statistik yang dijadikan pegangan maupun administrasi kependudukan yang belum lengkap dan masih dalam taraf pembinaan, namun secara kualitatif dapat diperoleh bahwa kehidupan sosial dan ekonomi di kota Sungailiat, banyak diwarnai dengan dinamika kegiatan sektor informal.

Atas dasar dinamika dan kegiatan sektor informal yang cukup menonjo di kota Sungailiat dimaksud inilah, sehingga studi ini dilakukan di lokasi penelitian. Untuk mempertajam penyelidikan dan analisa, kegiatan sektor informal dalam studi ini pada bidang penjual tetap yang terdiri dari penjual buah dan penjual pakaian.

Sebagaimana studi-studi terdahulu memaparkan, permasalahan tentang upaya pembinaan sektor informal khususnya dalam penjual buah-buahan dan pakaian di kota Sungailiat upaya meliputi pembinaan ketenagakerjaan dan penciptaan peluang kerja yang belum tertampung dalam sektor formal, khususnya menyangkut peningkatan pendapatan sebagai wujud dari intervensi pemerintah dalam aspek pembinaan keterampilan, pembinaan permodalan dan pembinaan organisasi.

\subsection{Rumusan Masalah}

Masalah yang akan dikaji dalam penelitian ini berkaitan dengan pengembangan sektor informal yang berkenaan dengan intervensi pemerintah berupa pembinaan sektor informal khususnya penjual buah-buahan serta penjual pakaian pada kota Sungailat Kabupaten Bangka dalam peningkatan penghasilan para pelaku sektor informal itu sendiri

Bekenaan dengan hal tersebut maka peranyaan yang timbul adalah :

1. Bagaimana bentuk intervensi pemerintah terhadap pelaku sektor informal.

2. Bagaimana dampak intervensi pemerintah terhadap peningkatan pendapat. 


\subsection{Tujuan Penelitian}

a. Untuk mendeskripsikan bagaimana bentuk intervensi pemerintah terhadap pelaku sektor informal.

b. Untuk menganalisis bagaimana dampak intervensi pemerintah terhadap peningkatan pendapatan pelaku sektor informal.

\subsection{Tinjauan Pustaka}

Tikson, (dalam Sani, 2000) menjelaskan bahwa terdapat beberapa kegiatan yang dapat dijadikan tolak ukur dalam proses pemberdayaan masyarakat yaitu :

\section{a. Pengorganisasian Masyarakat.}

Bidang ini berkenaan dengan peningkatan partisipasi masyarakat yang dapat dilakukan secara efektif melalui pengorganisasian . Masyarakat dapat diorganisasikan kedalam beberapa bentuk seperti organisasi kewilayahan yang luas, organisasi sektoral dan jaringannya atau aliansi dan koalisi. Organisasi-organisasi ini merupakan alat masyarakat untuk menyatakan kehendak mereka dan untuk memengaruhi proses perubahan yang diinginkan.

b. Penguatan Kelembagaan.

Kegiatan ini pada dasarnya merupakan penguatan kemampuan organisasi yang telah ada dengan meningkatkan unsur pengetahuan, keterampilan dan sumber daya yang termasuk di dalamnya proses perguliran, manajemen, kemandirian kelompok, norma dan nilai yang dianut organisasi agar kegiatan kolektif menjadi lebih efektif dan efisien. Dalam penerapannya penguatan kelembagaan banyak dilakukan melalui pelatihan keterampilan dan studi banding dilakukan untuk melihat kelompok ditempat lain yang telah berhasil meningkatkan produktivitas kerja organisasi.

c. Manajemen Sumber Daya Manusia.

Kegiatan ini menjamin bahwa kesejahteraan masyarakat dapat ditingkatkan apabila mereka mau mengelola sumber daya dengan baik termasuk didalamnya adalah kegiatankegiatan pengembangan organisasi sosial yang dapat melakukan fungsi pelayanan sosial seperti perumahan, pendidikan, kesehatan, rekreasi, transportasi dan kegiatan lain yang dianggap perlu. Disamping itu organisasi ekonomi diperlukan luas sehingga dapat memperluas lapangan kerja. Konservasi dan rehabilitasi lingkungan demi terciptanya pembangunan ekologi dan ekosistem juga mendapat perhatian.

Mac Pherson, (dalam Soetomo, 1987:26) mengatakan bahwa community development merupakan suatu gerakan yang dirancang memajukan kehidupan yang lebih baik seluruh komunita dengan pertisipasiaktif yang jika mungkin atas prakarsa masyarakat, tetapi jika prakarsa itu tidak datang secara spontan, digunakan teknik untuk merangsang dan membankitkannya dengan maksud mendorong tanggapan aktif dan antusias terhadap gerakan itu. lebih lanjut ia mengatakan bahwa pokok-pokok pikiran community development tersebut semakin memasyarakat secara internasional yang pada umumnya mengandung beberapa prinsip yaitu:

a. Mempersatukan usaha dari rakyat untuk rakyat dengan usaha pemerintah. 
b. Memajukan usaha ekonomi, sosial dan kebudayaan

c. Mengintegrasikan komunitas dengan masyarakat rasional. (Soetomo, 2006:99)

Dengan demikian maka community development adalah merupakan gerakan untuk membantu lapisan yang lemah dalam menghadapi yang kuat, dengan perkataan lain bahwa community development adalah perjuangan untuk melawan eksploitasi dengan muara perjuangan tersebut adalah perubahan struktural dan kultural. Dalam memahami pembangunan model ini, Cristenson dan Robinson, (dalam Soetomo, 1989 : 3) mengatakan bahwa community development dapat mengantisipasi permaalahan dan kebutuhan lokal serta dapat merumuskan program yang berdampak lokal. Hal ini disebabkan karena :

a. Sifatnya yang merangsang inisiatif lokal dan melibatkan masyarakat dalam perubahan sosial ekonomi.

b. Membangun saluran komunikasi dalam meningkatkan solidaritas.

c. Memperbaiki kesejahteraan pada level komunitas baik dalam aspek sosial, ekonomi, maupun kultural, (Soetomo, 2006:123).

Berdasarkan tiga rumusan program tersebut, maka dalam pelaksanaannya community development dapat melengkapi program-program pemerintah melalui hubungan kerja yang rasional dengan pemimpin dan tokhtokoh masarakat guna memecahkan masalah-masalah lokal yang diharapkan dapat mendorong warga masyarakat secara bersama-sama berinsiatif untuk melakukan tindakan sosial dengan atau tanpa bantuan pemerintah. Sejalan dengan itu maka dalam membangun ekonomi masyarakat diperlukan difusi modal, teknologi dan lembaga dari pemerintah kepada masyarakat.

Ketidakberayaan ekonomi suatu masyarakat ditandai engan adanya hambatan dalam pertumbuhan ekonomi. Menurut Hagen (dalam Cangara 2006:143) bahwa hambatan itu berupa terjadinya lingkaran setan antara pendapatan yang rendah yang mengakibatkan tidak mungkinnya terjadi pertambahan modal juga terjadinya demonstration effect, serta kondisi pasar yang tidak merangsang investasi baru. Hmbatan-hambatan seperti itulah yang meyebabkan terbentuknya kelompok marjinal di dalam kehidupan ekonomi.

Untuk memberdayakan kelompok marjinal perkotaan demikian diperlukan adanya intervensi dari kelompok eksternal yang lebih maju, atau perlu diberi bantuan agar kelompok marjinal dapat mengatasi ketidakberdayaan yang dialaminya. Dikatakan Nash (dalam Cangara. S, 2006:143) perlu dilakukan suatu transformasi dari suatu tipe umum perekonomian yang maju ke tipe perekonomian atau masyarakat miskin, karena itulah dalam kasus intervensi ini perlu dilakukan pemencaran atau diffusion dalam pertumbuhan ekonomi dan perubahan kultural. Teori Difusion dari Nash menyatakan bahwa pembangunan adalah pemencaran (diffusion) unsur-unsur kultural dari negara-negara maju ke negara-negara terbelakang.

Faktor yang perlu di difusikan adalah (1) Pengetahuan, Keterampilan, (3) Organisasi, (4) Nilai- 
nilai, (5) Teknologi, dan (6) Modal. Nash yakin dengan difusi maka secara bertahap masyarakat miskin pada negara-negara berkembang akan dapat memperbaiki kualitas kehidupan ekonomi mereka. Tanpa itu masyarakat akan terus terbelenggu oleh kemiskinan mereka (Nash dalam Cangara, S. 2006:143)

Pada difusi modal, Frank(1984: 34-35) menemukan bahwa ternyata lebih banyak menguntungkan ekonomi kuat (pusat) daripada ekonomi lemah (pinggiran), kelompok ekonomi kuat lebih banyak menarik surplus (sektor informal) daripada modal yang didifusikan kembali.

Menurut Evans (Syamsuri, 2002:21) memang hubungan ekonomi kuat lebih dominan dan berkemampuan dalam hal akumulasi modal, sehingga lebih banyak diuntungkan.

Akibat lanjut dari eksploitasi pada difusi modal dan lembaga-lembaga adalah munculnya "defrivation trap" yang terwujud dalam (a) kemiskinan, (b) kelemahan fisik, (c) keterasingan, (d) kerentanan, (e) ketidakberdayaan (Chambers dalam Cangara, S. 2006:152)

Kerentanan dan ketidakberdayaan adalah dua hal yang paling penting dari kelimanya. Kerentanan adalah ketidakmampuan masyarakat miskin untuk menyediakan sesuatu untuk menghadapi situasi darurat sehingga dapat berubah menjadi "roda penggerak kemiskinan" (poverty rackets). Sedangkan ketidak berdayaan adalah ketidakmampuan masyarakat miskin untuk melakukan pilihan-pilihan sesuai dengan yang diinginkan, sebagai akibat tidak adanya kekuatan pada posisi tawar (bargaining position) dalam menghadapi eksploitasi yang diterimanya. Ketidakberdayaan dan kerentanan dalam penelitian ini dimaknai sebagai ketidakberdayaan ekonomi.

Rendahnya

pendapatan menyebabkan tidak adanya kemungkinan untuk bertumbuhnya modal, selanjutnya ketiadaan pertumbuhan modal menyebabkan keuntungan atau pendapatan usaha menjadi rendah.

Jadi kemampuan pertumbuhan modal, kemampuan usaha menghasilkan surplus, dan ada tidaknya kerentanan usaha adalah indicator-indikator dari keberdayaan ekonomi pedagang informal.

\subsection{Skema Kerangka Pikir}

Berdasarkan dari tinjauan pustaka yang telah disampaikan di atas, maka penulis menyusun kerangka pikir sebagai berikut :

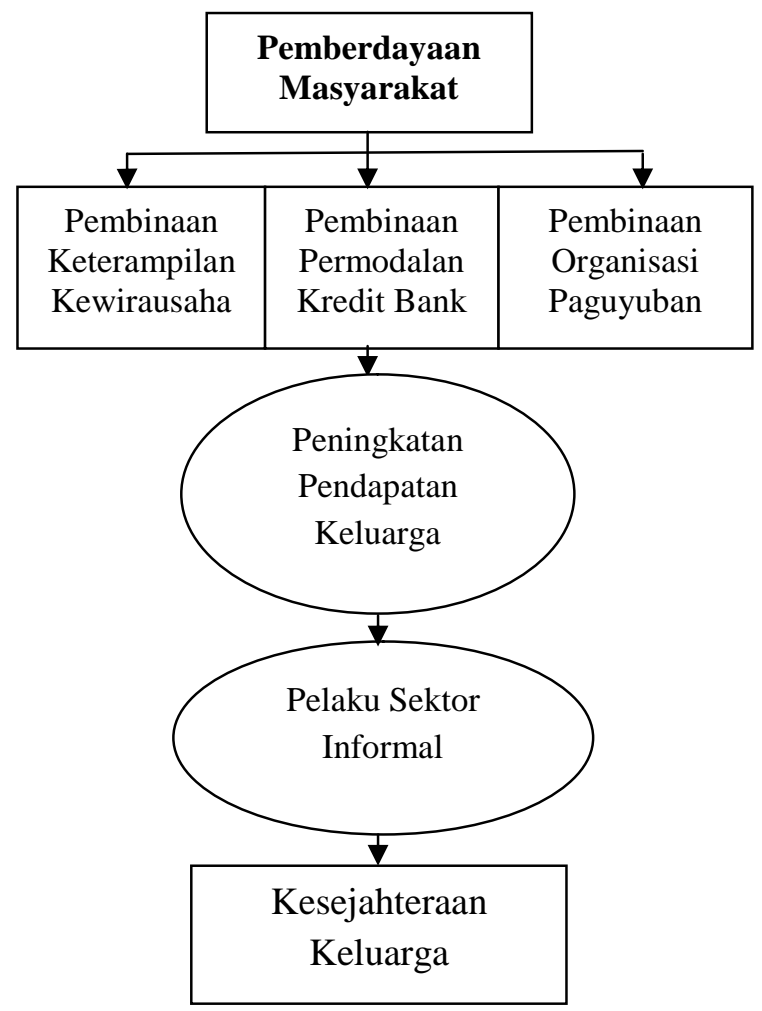


Gambaran

di

memperlihatkan bahwa pertumbuhan atau perkembangan usaha dari pelaku sektor informal dipengaruhi dari intervensi pemerintah dalam bentuk pembinaan pembekalan keterampila, pembinaan organisasi, dan termasuk bantuan permodalan, sehingga terdapat keberdayaan masyarakat utamanya terhadap pelaku sektor informal khususnya dalam upaya peningkatan pendapatan yang berimplikasi terhadap kesejahteraan keluarga.

\section{METODE PENELITIAN}

\subsection{Tipe Penelitian}

Berdasarkan dari pada tujuan penelitian ini maka jenis penelitian adalah tipe penelitian deskriptif kualitatif dengan dasar (metode) studi kasus. Dalam hal ini fenomena yang akan dianalisa secara mendalam adalah pedagang kakilima di sektor informal di pasar ikan Kelurahan Sungailiat Kabupaten Bangka.

Sedangkan pendekatan yang digunakan dalam penelitian ini adalah pendekatan kualitatif. Dengan pendekatan kualitatif, maka data-data yang diperoleh dalam prosedur penelitian ini merupakan data deskriptif, yakni data-data dalam bentuk kata-kata tertulis atau lisan serta hasil pengamatan perilaku dari orang-orang yang diamati (Bogdan dan Taylor dalam Moleong, $2000: 3$ )

\subsection{Waktu dan Tempat Penelitian}

Penelitian ini dilakukan di kawasan Pasar Ikan yang berlokasi di Kelurahan Sungailiat Kecamatan Sungailiat Kabupaten Bangka Propinsi
Kepulauan Bangka Belitung sebagai wilayah sampel. Pemilihan lokasi ini dilakukan secara purposive (disengaja) yang didasarkan atas pertimbangan :

- Bahwa di lokasi ini banyak terdapat pedagang kakilima.

- Umumnya berasal dari berbagai karakteristik.

Adapun waktu penelitian dilaksanakan selama 2 dua) bulan yakni bulan Januari s/d bulan Februari 2010.

\subsection{Teknik Penentuan Informan}

Informan adalah orang yang dimanfaatkan untuk memberikan informasi tentang situasi dan kondisi latar penelitian (Moleong dalam E. Pandu, 2006 : 121). Dalam penelitian ini penentuan informan utama (informan kunci) maupun informan penunjang dilakukan secara sengaja (purposive). Walaupun demikian untuk informan utama (informan kunci), berhubung pelaku sektor informal yang bekerja sebagai pedagang kakilima yang menjadi obyek penelitian terbagi kedalam kelompok-kelompok tertentu, maka dalam penentuan informan utama (informan kunci) secara purposive juga.

Sehubungan dengan penelitian yang dilakukan ternyata data dan informan yang dibutuhkan berkaitan dengan pokok permasalahan utama penelitian sudah dapat diperoleh dari kasus pedagang kakilima di Pasar Ikan Kelurahan Sungailiat berdasarkan kriteria yang sudah ditentukan, maka peneliti memutuskan berhenti pada jumlah informan utama (informan kunci) sebanyak 7 keluarga pedagang kakilima saja. Dari 7 kasus pedagang kakilima tidak ditemukan informasi yang sangat 
bervariasi tetapi informasi ang berkaitan dengan pokok permasalahan utama penelitian cenderung mengarah ke kesamaan.

\subsection{Teknik Pengumpulan Data}

Teknik yang dipergunakan untuk pengumpulan data dalam penelitian ini adalah dengan cara : observasi, Interview mendalam dan pedoman wawancara.

\subsection{Teknik Analisis Data}

Analisis data merupakan upaya mencari dan menata secara sistematis catatan hasil observasi, wawancara untuk meningkatkan pemahaman peneliti tentang kasus yang diteliti, meningkatkan pemahaman ini dilakukan dengan berupaya mencari makna, setelah itu menyajikan hasil analisis ini sebagai temuan bagi orang lain (Muhajir dalam E. Pandu, 2006 : 126).

Untuk mendapatkan hasil analisis yang dapat dipertanggungjawabkan sesuai dengan permasalahan penelitian ini maka unit analisis ditentukan adalah kelompok pedagang kakilima di seputar Pasar Ikan Kelurahan Sungailiat.

Sehubungan dengan pendekatan yang digunakan dalam penelitian ini adalah penelitian kualitatif, maka teknik analisis data yang digunakan adalah teknik analisis induktif-kualitatif; dimana penelitian kualitati tidak mencari bukti untuk menerima atau menolak suatu hipotesis yang dirumuskan sebelum peneliti memasuki lapangan, (Handayani dan Sugiarti dalam E. Pandu, 2006 : 127).

Untuk memudahkan dalam mengumpukan hasil temuan di lapangan digunakan matriks yang disusun berdasarkan matriks yang digunakan pada teknik analisis komponensial yang dimodifikasi sesuai kebutuhan, sebagai contoh analisis berikut ini :

\begin{tabular}{ll} 
Komponen & \multicolumn{1}{c}{ Pedagang Kakilima } \\
\cline { 2 - 2 } Pandangan & $\begin{array}{l}\text { Difusi Modal } \\
\text { Teoritis } \\
\text { Rendahnya Pendapatan, } \\
\text { ketiadaan pertumbuhan modal } \\
\text { menyebabkan } \\
\text { Keuntungan atau pendapatan } \\
\text { usaha menjadi rendah }\end{array}$ \\
& $\begin{array}{l}\text { Tiga pendekatan } \\
\text { Pemberdayaan: } \\
\text { Bantuan Modal. } \\
\text { Pendidikan } \\
\text { Pelatihan/Keterampilan } \\
\text { Pembinaan Organisasi }\end{array}$ \\
\hline
\end{tabular}

Temuan Lapangan

Kasus-kasus 1s/d 7

Untuk menyimpulkan ada tidaknya dampak intervensi pemerintah terhadap peningkatan pendapatan masyarakat digunakan indikator-indikator sebagai ukuran antara lain :

Dampak intervensi pemerintah terhadap peningkatan pendapatan diukur melalui adanya perlakuan kepada "pedagang kakilima" dalam :

- Akses terhadap bantuan permodalan.

- Akses dalam pendidikan pelatihan dan keterampilan.

- Akses dalam pembinaan organisasi.

\section{PEMBAHASAN}

\subsection{Kasus Tujuh Orang Pedagang} Kakilima Disekitar Pasar Ikan

\section{Kelurahan Sungailiat}

Ketujuh pedagang kakilima yang menjadi informan dalam penelitian ini diasarkan pada tiga kriteia pokok yang 
menjadi acuan bagi penelitian ini. Ketiga kriteria tersebut adalah pertama, pedagang kakilima yang belum berumah tangga dan kedua, pedagang kakilima yang sudah berumah tangga dan yang ketiga pedagang kakilima yang telah melakukan kegiatan kewirausahaan ini selama kurun waktu 0 -5 tahun dan 5 tahun keatas, dengan masing-masing kelompok berjumlah dua orang sebagai informan.

\subsection{Bentuk Intervensi Pemerintah Terhadap Pelaku Sektor Informal}

Untuk memberdayakan kelompok marjinal perkotaan demikian diperlukan adanya intervensi dari kelompok eksternal yang lebih maju, atau perlu diberi bantuan agar kelompok marjinal dapat mengatasi ketidakberdayaan yang dialaminya. Dikatakan Nash (dalam Cangara,S.2006:143) perlu dilakukan suatu transformasi dari suatu tipe umum perekonomian yang maju ke tipe perekonomian atau masyarakat miskin.karena itulah dalam kasus intervensi ini perlu dilakukan pemencaran atau "diffusion" dalam pertumbuhan ekonomi dan perubahan kultural.

Adapun bentuk intervensi yang perlu dilakukan pemerintah sebagai pemencaran atau diffusion termasuk di dalamnya adalah aspek keterampilan (pendidikan/pelatihan), permodalan, dan pembinaan organisasi.

\section{a. Aspek Pelatihan Keterampilan}

Banyak pekerjaan di dalam sektor informal yang tidak memerlukan keterampilan sepert halnya, kuli pelabuhan, buruh lepas, penjaja rokok, pengumpul barang-barang bekas namun banyak pula yang memerlukan keterampilan terutama dalam kegiatan usaha mandiri seperti halnya penjual buah, pakaian, asesoris, pembantu, tukang batu, pengecat dan sebagainya.

Keadaan umum yang berlaku dalam sektor informal seperti yang diuraikan di atas, berlaku pula dalam kehidupan berusaha para pedagang kakilima di Kelurahan Sungailiat. Pedagang kakilima yang menjual buah, pakaian, asesoris dan beberapa bentuk kegiatan lainnya tentu saja harus mempunyai keterampilan khusus yang berhubungan dengan jualan yang ditawarkannya. Dari informan pedagang kakilima yang dijumpai.

"Seperti pada kasus Yen/38 tahun berasal dari Padang, misalnya yang merupakan salah satu penjual pakaian menyatakan, bahwa sejak awal dan menetap di Bangka sampai sekarang telah menjual pakaian karena mencari kerjaan pada sektor lain (formal) sangatlah sulit sementara bekerja di TI (tambang inkonveisional) dengan dua orang anak yang menjadi tanggungan terkadang penghasilan tidaklah mencukupi bahkan jauh dari cukup. Kendala yang dihadapi dalam mengembangkan usaha ada dua hal petama adalah faktor modal karena kalau kita memiliki sedikit modal sangat sulit untuk meningkatkan pendapatan karena modal itulah yang diputar, variasi jenis jualan juga terbatas (tidak lengkap) jadi banyak pembeli biasanya beralih membeli di toko-toko pakaian terdekat, dan kedua keterampilan berusaha, karena banyak diantara kita beralih kesektor ini karena minimnya keterampilan serta 
tidak terakses pada sektor formal jadi kami melihat pendidikan pelatihan sangat dibutuhkan. Selama saya jualan baru satu kali dapat kesempatan mengikuti pelatihan keterampilan usaha yang difasilitasi oleh PT.Timah Tbk bekerja sama dengan Departemen Koperasi kala itu".(Dialog dengan Yen pedagang pakaian, hari Minggu tanggal 10 Januari 2010)

Berdasarkan hasil wawancara dengan informan sebagaimana yang dikemukakan oleh Yetendra di atas menunjukkan bahwa untuk kegiatann usahanya diperlukan keterampilan. Hal ini dapat dimaklumi, karena setiap kegiatan usaha memerlukan keterampilan tersendiri seperti halnya pedagang buah, pakaian, makanan dan sebagainya.

Pembinaan keterampilan dianggap penting oleh informan (pedagang kakilima) yang menjual barang dagangannya berupa buah-buahan adalah keterampilan menata serta merawat agar awet dan kelihatan tetap segar, sedangkan pembinaan keterampilan yang dianggap penting oleh pedagang kakilima yang berdagang pakaian adalah pembinaan keterampilan selain menata memahami selera konsumen terhadap barang yang lagi trendi dan tatkala pentingnya adalah memenaj keluar masuknya barang termasuk keuangan dalam pembukuan yang baik.

\section{b. Aspek Permodalan}

Secara umum, kemampuan satu unit kegiatan usaha akan ditentukan oleh faktor manusia dan sarana yang terkait di dalamnya. Faktor manusia tercakup didalamnya sifat pribadi dan keterampilan, dimana sifat pribadi akan lebih banyak ditentukan oleh pribadi dan falsafah hidupnya yang selanjutnya akan lebih menemukan motivasinya sedangkan keterampilan dapat diperoleh melalui pendidikan serta pengalamannya, sementara sarana usaha yang berupa tempat usaha, perlengkapan, barang yang didagangkan, maupun tidak terlihat seperti organisasi, sistem prosedur dan pembinaan usaha. Pembinaan dalam hubungannya dengan kegiatan usaha dikalangan pedagan kakilima di kota Sungailiat, pada umumnya adalah berupa pembinaan permodalan.

Adapun bentuk bantuan permodalan oleh pedagang kakilima sebagaimana yang dituturkan oleh Er adalah :

"Permasalahan kita hanya pada permodalan sehingga kita sangat berharap pada pemerintah untuk dapat lebih memperhatikan kita dengan memberikan bantuan modal usaha karena sejak awal saya merintis usaha ini belum pernah mendapatkan bantuan dari pemerintah berupa pinjaman bergulir sebagaimana pada pedagang kakilima dibeberapa daerah yang pernah saya jajaki, kecuali dengan usaha secara mandiri mencoba mengajukan bantuan kredit pada Bank yang memberikan pinjaman dengan sedikit persyaratan karena kebanyakan dari kita calon nasabah ini sangat sulit mendapatkan bantuan pinjaman karena persyaratan yang begitu banyak dan semua itu biasanya tidak lepas dari biaya-biaya administrasi yang terkadang tidak sedikit bagi level kita. 
Sejak saya jualan sudah dua kali mengajukan permohonan bantuan pinjaman modal melalui Bank Syariah Kabupaten Bangka karena pada Bank ini persyaratanya tidaklah terlalu sulit jika dibandingkan pada Bank-Bank lainnya". (Dialog dengan Er pedagang Pakaian hari Jum'at 22 Januari 2010).

Lebih kurang sama seperti yang dikemukakan oleh Yen bahwa bantuan dalam bentuk permodalan dalam menjalankan usaha pedagang kakilima membutuhkan bantuan modal sebagaimana dalam penuturan berikut :

"Untuk itu dalam upaya meningkatkan pendapatan saya sudah dua kali mengajukan permohonan pinjaman kredit di Bank pertama pada Bank BRI Unit Sungailiat dan selanjutnya setelah pinjaman pertama lunas saya kembali mengajukan pinjaman, tapi pada pinjaman kedua melalui Bank Syariah Kabupaten Bangka."

Dari hasil penelitian lapangan memberikan gambaran bahwa informan memandang perlunya pemerintah turut campur tangan dalam bentuk pembinaan atau bantuan permodalan kepada para pedagang kakilima berupa bantuan langsung seperti dana bergulir, serta mempermudah urusan administrasi dalam mengakses pinjaman kredit pada bank dalam upaya meningkatkan volume usaha serta pendapatan bagi pedagang kakilima itu sendiri.

\section{c. Pembinaan dalam Aspek Organisasi}

Dalam dunia usaha yang semakin kompleks ini sulitlah bagi usaha-usaha perorangan untuk dapat bekembang atau untuk dapat menghindarkan diri dari kegagalan-kegagalan apalagi tidak menjalin kerjasama dengan pengusahapengusaha yang lain. Koperasi dan asosiasi adalah wadah-wadah yang tepat untuk melakukan kerjasama antara usaha-usaha tersebut, karena bentuk organisasi ekonomi tersebut bertujuan untuk memberikan pelayanan kepada anggota-anggotanya dalam rangka memajukan usaha milik para anggota.

Hanya saja dari hasil penelitian dilapangan mengambarkan kepada kita bahwa para pedagang kakilima di kota Sungailiat belum terhimpun dalam suatu organisasi atau asosiasi seperti koperasi sebagaimana yang disampaikan oleh informan kita Et sebagai berikut :

"Keprihatinan saya selaku penjual khususnya sebagai pedagang kakilima kita tidak punya payung hukum sehingga posisi kita sangat lemah dan untuk menggalang kerja sama dan solidaritas anggota sesama pedagang kakilima di kota Sungailiat kita punya paguyuban baik sebagai penjual pakaian maupun sebagai penjual buah rutin pada setiap bulannya mengadakan pertemuan sesama temanteman dari penjual dipasar Sungailiat ini bentuknya semacam arisan anggota pada setiap bulannya dan lumayan untuk menambah modal kita." ( Dialog yang ke dua kalinya dengan Et, Rabu Siang tanggal 10 Februari 2010) 
Hasil penelitian berdasarkan wawancara di atas, menunjukkan bahwa pedagang kakilima belum terhimpun dalam organisasi ekonomi secara formal seperti koperasi dan asosiasi lainnya. Kenyataan ini dalam kaitannya dengan pedagang kakilima di kota Sungailiat, ternyata pada umumnya pedagang kakilima belum menjadi anggota koperasi, kecuali organisasi dalam bentuk paguyuban oleh pedagang kakilima itu sendiri dengan tujuan membangun aksi solidaritas kelompok sesama pedagang kakilima dalam bentuk arisan bulanan sekaligus menjadi suntikan modal bagi kegiatan usahanya yang mendapatkan undian dalam arisan tersebut.

\subsection{Dampak Intervensi Pemerintah} Terhadap Peningkatan Pendapatan Pedagang Sektor Informal

Seperti dikemukakan sebelumnya bahwa ketergantungan para pedagang kakilima akan bantuan kredit baik dalam bentuk modal financial maupun dalam bentuk kredit berupa bahan baku boleh jadi menjadi salah satu penyebab utama yang mendasari tingkat kesejahteraan ekonomi mereka tetap berada pada kondisi yang stagnan.

Adapun gambaran pedapatan pedagang kakilima sebagai dampak intervensi pemerintah dapat dilihat bagaimana besar tingkat pendaptan sebelum dan sesudah adanya intervensi dari pemerintah:
Tabel 3.1

Profil Dampak Intervensi Pemerintah Terhadap Peningkatan Pendapatan Keluarga Informan

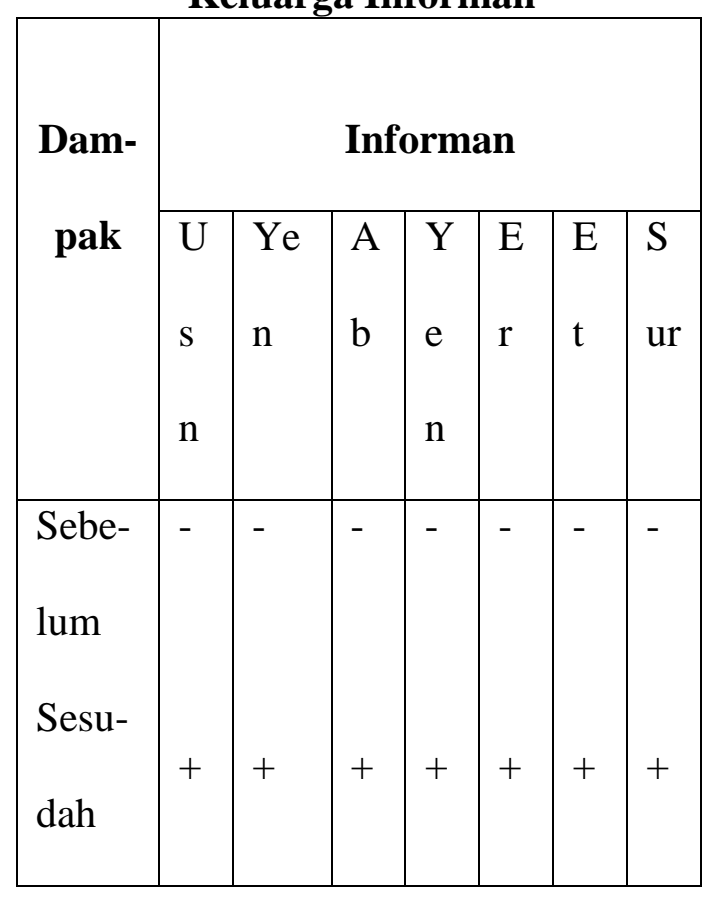

Keterangan : Tanda - berarti negatif dan tidak berkembang sementara Tanda + berarti positif dan berkembang

Untuk memahami dampak inervensi terhadap peningkatan pendapatan pada keluarga informan sebaiknya mari kita lihat bagaimana latar belakang mata pencaharian hidup yang identik dengan tingkat pendapatan informan sebelum memasuki sektor informal khususnya sebagai pedagang kakilima.

\subsection{Analisis Terhadap Peningkatan Pendapaan Pedagang Kakilima}

Pada umumnya pedagang kakilima melakukan kegiatan usaha lebih disebabkan oleh faktor kebutuhan ekonomi untuk bertahan hidup (survival) mengingat penghasilan mereka belum bisa mencukupi kebutuhan ekonomi 
keluarga yang bekerja sebagai penambang timah, nelayan maupun yang bekerja sebagai buruh bangunan. Selain itu terdapat nilai-nilai yang sepertinya sudah tertanam pada diri mereka dari generasi kegenerasi sehingga menjadi budaya. Nilai-nilai tersebut adalah nilai kawa (nilai harga diri atau martabat) yang menjadi faktor pendorong keterlibatan pedagang kakilima dalam kegiatan ekonomi produktif agar kebutuhan rumah tangga mreka senantiasa terpenuhi.

Fenomena tersebut terefleksikan dalam ungkapan perihal pendapatan mereka dengan mengemukakan bahwa " aduuh kasian ", dikit bae dak banyak ( sedikit saja dan tidak banyak). Atau dengan menggunakan kata-kata seperti “ dak banyak, tapi adelah yang penting ade gawe dan kawa dak ngemis ke' orang" (tidak banyak tetapi pastinya ada, yang penting ada kegiatan serta kemauan dan tidak meminta /mengemis dengan orang lain). Sehingga dengan demikian, pedagang kakilima di Kelurahan Sungailiat yang berasal dari berbagai daerah dengan kelompok etnik dan budaya yang beragam bekerja karena memang harus bekerja untuk mencari nafkah dalam rangka menutupi kebutuhan ekonomi keluarga.

Sejalan dengan apa yang dikatakan oleh Nash (dalam Cangara,S .2006:143) perlu dilakukan suatu transformasi dari suatu tipe umum perekonomian yang maju ke tipe perekonomian atau masyarakat miskin.karena itulah dalam kasus intervensi ini perlu dilakukan pemencaran atau "diffusion" dalam pertumbuhan ekonomi dan perubahan kultural.
Dalam pada itu, dengan intervensi dalam aspek modal melalui pinjaman kredit pada bank dan rentenir kegiatan usaha para pedagang kakilima pada dasarnya dapat dikembangkan karena mereka dapat memperoleh keuntungan dari kegiatan usaha dengan bekerja sebagai pedagang kakilima. Dari kelompok yang berpenghasilan kecil karena memang tidak memiliki modal usaha sampai pada kelompok yang memiliki kemampuan untuk dapat mengembalikan pinjaman kredit dari bank sekaligus menutupi kebutuhan ekonomi keluarga. Selanjutnya, peninggkatan keterampilan melalui pelatihan pendidikan keterampilan menjadi sangat penting mengingat tingkat pendidikan formal mereka yang rata-rata tamat SMA ditambah dengan faktor modal yang mereka miliki sangat terbatas, menjadikan pedagang kakilima tidak memiliki alternatif lain dalam memilih jenis pekerjaan, sebagaiamana dalam petikan dialog bersama dengan Yen :

"Seperti pada kasus Yetendra/38 tahun berasal dari Padang, misalnya yang merupakan salah satu penjual pakaian menyatakan, bahwa sejak awal dan menetap di Bangka sampai sekarang telah menjual pakaian karena mencari kerjaan pada sektor lain (formal) sangatlah sulit sementara bekerja di TI (tambang inkonveisional) dengan dua orang anak yang menjadi tanggungan terkadang penghasilan tidaklah mencukupi bahkan jauh dari cukup. Kendala yang dihadapi dalam mengembangkan usaha ada dua 
hal petama adalah faktor modal karena kalau kita memiliki sedikit modal sangat sulit untuk meningkatkan pendapatan karena modal itulah yang diputar, variasi jenis jualan juga terbatas (tidak lengkap) jadi banyak pembeli biasanya beralih membeli di tokotoko pakaian terdekat, dan kedua keterampilan berusaha, karena banyak diantara kita beralih kesektor ini karena minimnya keterampilan serta tidak terakses pada sektor formal jadi kami melihat pendidikan pelatihan sangat dibutuhkan. Selama saya jualan baru satu kali dapat kesempatan mengikuti pelatihan keterampilan usaha yang difasilitasi oleh PT.Timah Tbk bekerja sama dengan Departemen Koperasi kala itu."(Dialog dengan Yen pedagang pakaian, hari Minggu tanggal 10 Januari 2010)

Harapan Yen senada dengan Er, sebagaimana dalam petikan wawancara berikut :

"Permasalahan kita hanya pada permodalan sehingga kita sangat berharap pada pemerintah untuk dapat lebih memperhatikan kita dengan memberikan bantuan modal usaha karena sejak awal saya merintis usaha ini belum pernah mendapatkan bantuan dari pemerintah berupa pinjaman bergulir sebagaimana pada pedagang kakilima dibeberapa daerah yang pernah saya jajaki, kecuali dengan usaha secara mandiri mencoba mengajukan bantuan kredit pada Bank yang memberikan pinjaman dengan sedikit persyaratan karena kebanyakan dari kita calon nasabah ini sangat sulit mendapatkan bantuan pinjaman karena persyaratan yang begitu banyak dan semua itu biasanya tidak lepas dari biaya-biaya administrasi yang terkadang tidak sedikit bagi level kita. Sejak saya jualan sudah dua kali mengajukan permohonan bantuan pinjaman modal melalui Bank Syariah Kabupaten Bangka karena pada Bank ini persyaratanya tidaklah terlalu sulit jika dibandingkan pada Bank-Bank lainnya. (Dialog dengan Er pedagang Pakaian hari Jum'at 22 Januari 2010)

Dari dua petikan wawancara bersama dengan informan di atas bantuan /intervensi berupa bantuan modal dan pelatihan pendidikan keterampilan dibutuhkan bagi informan guna meningkatkan volume usahanya untuk mendapatkan penghasilan yang lebih baik.

Penting untuk diingat bahwa meskipun pendapatan mereka tergolong pas-pasan, namun tidak jarang mereka gunakan untuk membeli barang-barang kebutuhan sekunder yang memerlukan biaya relatif lebih mahal daripada sekedar untuk memenuhi kebutuhan hidup sehari-hari. Inipun pada dasarnya bisa dimaklumi oleh karena tingkat pendidikan mereka yang masih sangat terbatas sehingga menyebaban kesadaran akan perencanaan dalam skala perioritas kebutuhan hidup sangat bercorak konsumtif dengan gaya hidup konsumerisme, yakni pemenuhan akan kebutuhan secara berlebihan demi naiknya gengsi. 
Dengan gaya hidup konsumerisme sebagaimana tersebut di atas, maka program pemberdayaan masyarakat yang dicanangkan pemerintah Kabupaten Bangka melalui pemberian bantuan modal usaha diduga tidak akan menghasilkan perubahan yang cukup signifikan dalam konteks perubahan pola perilaku para penggiat usaha pedagang kakilima. Maka dari itu, menurut hemat penulis untuk lebih mengefektifkan program pemberdayaan tersebut akan lebih baik jika pemerintah menekankan pula aspek perubahan pola pikir masyarakat khususnya pola pikir para penggiat kegiatan usaha pedagang kakilima itu sendiri.

\section{Tabel 3.2}

Profil Bentuk Intervensi Pemerintah Terhadap Informan Pedagang Kakilima

\begin{tabular}{|c|c|c|c|c|c|c|c|}
\hline \multirow[t]{2}{*}{ Bentuk } & \multicolumn{7}{|c|}{ Informan } \\
\hline & $\begin{array}{l}\mathrm{U} \\
\text { sn }\end{array}$ & $\begin{array}{l}\text { Y } \\
\text { en }\end{array}$ & $\begin{array}{l}\text { A } \\
\text { b }\end{array}$ & $\begin{array}{l}\mathrm{E} \\
\mathrm{r}\end{array}$ & $\begin{array}{l}E \\
t\end{array}$ & $\begin{array}{l}\mathrm{Aa} \\
\mathrm{m}\end{array}$ & $\begin{array}{l}\mathrm{S} \\
\text { ur }\end{array}$ \\
\hline $\begin{array}{l}\text {-Aspek } \\
\text { pendidika } \\
\text { n/ }\end{array}$ & - & + & - & - & - & - & - \\
\hline $\begin{array}{l}\text { Keterampi } \\
\text { lan } \\
\text {-Aspek } \\
\text { Permodala } \\
\mathrm{n} \\
\text {-Aspek } \\
\text { pembinaan } \\
\text { organisasi }\end{array}$ & * & $*$ & $*$ & $*$ & $*$ & $*$ & * \\
\hline
\end{tabular}

Keterangan : Tanda + ada/mendapatkan, Tanda - berarti tidak ada/tidak mendapatkan, Tanda * berarti ada dengan inisiatif pedagang kakilima itu sendiri.

Dari tabel 3.4.1 profil bentuk intervensi pemerintah terhadap keluarga informan pedagang kakilima dapat dijelaskan bahwa bentuk intervensi pemerintah terhadap pedagang kakilima dalam aspek pendidikan pelatihan keterampilan rendah, dari tujuh orang informan hanya satu diataranya yang pernah mendapatkan pelatihan kewirausahaan, sementara dalam aspek permodalan tergolong besar dalam arti dari tujuh orang informan enam orang di antaranya pernah mendapatkan bantuan modal berupa pinjaman kreedit dari bank BRI dan Bank Syariah kecuali satu diantaranya pada kasus Sur beralih pada rentenir karena sulitnya mengakses pinjaman dari Bank setelah ditunggu dari sekian lama setelah pengajuan tidak kunjung keluar dan dalam aspek pembinaan organisasi sangat-sangat rendah dan bahkan dapat dikatakan tidak ada kecuali inisisatif pedagang kakilima itu sendiri dengan membentuk paguyuban dalam bentuk arisan bulanan.

\section{PENUTUP \\ 4.1 Kesimpulan}

Dari hasil pembahasan dan analisis kasus tersebut di atas, maka dapatlah diketengahkan sebagai kesimpulannya adalah sebagai berikut :

1. Bentuk intervensi pemerintah sebagai pemberdayaan terhadap sektor informal pada pedagang kakilima di seputar pasar Ikan Kelurahan Sungailiat tidak diketemukan adanya pemberdayaan dalam aspek pembinaan organisasi kecuali inisiatif pedagang kakilima itu sendiri dengan membentuk kelompok paguyuban pedagang kakilima kelurahan Sungailiat.

2. Pelaksanaan program intervensi sebagai bentuk pembedayaan 
masyarakat khususnya pedagang kakilima di seputar Pasar Ikan Kelurahan Sungailiat dalam aspek permodalan berdampak positif terhadap peningkatan pendapatan bagi pedagang kakilima.

\subsection{Saran}

1. Pedagang kakilima di Kelurahan Sungailiat memiliki kemampuan menciptakan lapangan kerja baik untuk dirinya sendiri, keluarga dan masyarakat disekitarnya serta mampu memberikan pendapatan yang cukup besar bagi dirinya, keluarga dan para pekerjanya. Untuk itu perlu pengakuan yang lebih nyata terhadap kegiatan usaha yang dijalankan oleh pedagang kakilima tersebut terutama dari pihak-pihak terkait seperti perbankan ataupun pihak pemerintah daerah sebagai implementasi dari pemberdayaan masyarakat.

2. Dari segi skala usaha, kegiatan usaha yang dilakoni oleh para pedagang kakilima di Kelurahan Sungailiat cukup besar baik dari segi tenaga kerja, sumbangan pendapatan terutama pada usaha jual buah dan pakaian. Untuk itu diharapkan agar pemerintah daerah lebih memperhatikan kegiatan-kegiatan usaha pelaku pedagang kakilima tersebut terutama terkait dengan masalah permodalan, pembekalan/pelatihan pendidikan keterampilan dan pembinaan organisasi dalam upaya peningkatan pendapatan masyarakat khususnya pelaku pedagang kakilima itu sendiri.

\section{DAFTAR PUSTAKA}

Bagong Suyanto dan Karnaji, 2005. Kemiskinan dan Kesenjangan Sosial, Airlangga University Press, Surabaya.

Bodhan, 2001. Metodologi Penelitian Kualitatif, PT.Raja Grafindo Persada, Jakarta.

Cangara, S. 2006. Pengaruh Eksploitasi Difusi Modal dan Lembaga, Internalisasi Nilai Agama Islam dan Budaya Siri Terhadap Keberdayaan Ekonomi dan Karsa Dalam Kehidupan Sosil Ekonomi, Disertasi, Universitas Padjadjaran, Bandung.

Czuba, Cheryl, 2000. Empowermet, zuba a caurt, Michigan Cag Uncom Edu

Darmawan, S. Kuliah Perencanaan dan Pembangunan Sosial, Tanggal 7 April 2009, Makassar.

Dewi, K. 1987. Pendidikan yang Diperukan Dalam Pengembangan Kemandiran Wanita, Yayasan Annisa, Yogyakara.

Faisal, Sanapiah, 1999. Format-format Penelitian Sosial. Rajawali Press, Jakarta.

Farooq, G.M. 1984. Population and Employment in Developing Countrie, ILO, Geneva.

Frank,A.G. 1984. Sociology of development and underdevelopment of sociology. Terjemahan Pustaka Pulsar. 
PT. Sangkala Pulsar Indonesia. Jakarta.

Friedman Jhon, 1992. Empowerment; The Politics Of Alternative Developmet, Blacwell Publisher, Cambridge.

Goleman, Daniel. 2003. Emotional Inelegence (Kecerdasan Emosional), PT. Gramedia Putaka Utama, Jakarta.

Hart, K. 1985. Sektor Informal, Dalam Manning an Effendi T.H. Ubanisasi, Pengangguran, dan Sektor Informal Di Kota, PT. Gramedia, Jakart.

Hart, K. 1993. Informal Income Opportunities and Urban Employment in Ghana Journal of Modern African Studies, Vol. II, No 4.

Hidayat, 1978. Sektor Informal dan Struktur Ekonomi Indonesia, Lembaga Penelitian Sosial Universitas Indonesia, Jakara. 1985, Migrasi Tenaga Kerja dan Pembangunan Ekonomi, Lembaga Demogrfi Fakultas Ekonomi Universitas Indonesia, Jakata.

, 1988, Posisi dan Peran Strategis Sekor Informal Dalam Perekonomian Indonesia. Makalah dalam seminar Mobilitas Penduduk dan Sektor Infomal diselenggarakan oleh Pusat Studi Kependudukan UGM, Yogyakart.
Johnson. D.P. 1996. Soiologial Theory Classial founders and Contemporery Perspektives. Alih Bahasa Lawang, MZ. Tori Sosiologi Klasik danMdern. Grmedia, Jakarta.

Karnaji, 2008. Nadi Kehidupan Kota itu Bernama PKL. (online).http/www.kompas.com/ kompas.ceak/10204/Jatim/nadi39. htm. diakses 15 Oktober 2009.

Kartasasmita, Ginanjar, 1996. Pemberdayaan Masyarakat, Pembangunan yang berakar pada Masyarakat, Bappenas, Jakarta.

Koentjaraningrat, 1989. Kebudayaan Mentalitas dan Pembangunan, Gramedia, Jakarta.

Koordinator Statistik Kecamatan Sungailiat, 2008. Kecamatan Sungailiat Dalam Angka 2008, Badan Pusat Statistik Kabupaten Bangka, Sungailiat Bangka.

Laeyendecker, 1983. Tata, Perubahan dan Ketimpangan Suatu Pengantar Sejarah Sosiologi, Gramedia, Jakarta.

Manning, Chris \& Tajuddin Noer Effendi, 1996. Urbanisasi, Pengangguran dan Sektor Informal di Kota, Yayasan Obor Indonesia, Jakarta.

Maria E. Pandu, 2006. Gender Di Tanah Mandar Studi Kasus Kesetaraan dan Kemitraan Terpadu pada Komunitas Nelayan Mandar di Lingkungan Ranggas Barat, Kelurahan Totoli,Kecamatan 
BanggaE, Kabupaten Majene,

Disertasi, Universitas Hasanuddin, Makassar.

Moleong, Lexy J. 2002. Metodologi Penelitian Kualitatif. PT.Remaja Rosdakarya, Bandung.

Nasikun, 1980. Urbanisasi Berlebih, involusi Perkotaan dan Radikalisme Politik di Negaranegara berkembang. Prisma.

Nasution, M.Z.. 1988. Sektor Informal di Perkotaan. Makalah dalam Seminar Mobilitas Penduduk dan Sektor Informal Puat Studi Kependudukan UGM, Yogyakarta.

Pamudji, 1985. Pembinaan Perkotaan di Indonesia, Bina Aksara, Jakarta.

Poloma, Margare M..1992. Sosiologi Kontemporer. Rajawali Presss, Jakarta.

Rachbini, D.J. 1994. Ekonomi Informal Perkotaan.Pustaka, Jakarta.

Ramli, R. 1992. Sektor Informal Perkotaan Pedagang Kakilima .Indonesia. Hill,Co. Jakarta.

Ritzer, George, 1992. Sosiologi Ilmu Pengetahuan Beparadigma Ganda, Rajawali Press. Jakarta.

Rusminto Isbandi Adi, 2008. Intervensi Komunitas Pengembangan Masyarakatsebagai Upaya Pemberdayaan Masyarakat, PT Raja Grafindo, Jakarta.

Sahertian, Piet A. dan Ida Alacida

Sahertian. Model Latihan
Kepemimpinan, Usaha Nasional, Surabaya.

Sairin, Sjafri. 2002. Perubahan Sosial Masyarakat Indonesia. Perspektif Antropologi. Pustaka Pelajar. Yogyakarta.

Sani,M.Y, 2000. Manusia, Kebudayaan dan Pembangunan, Laboratorium Pembangunan Masyarakat, Program Pascasarjana Unhas, Makassar.

Simanjuntak, P.Y. dan Pasaribu, 1980. Membina dan Mengembangkan Generasi Muda. Transito, Bandung.

Sugiyono. 2008. Memahami Penelitian Kualitatif. CV. Alfabeta, Bandung.

Suharto, Edi, 2005.Membangun Masyarakat Memberdayakan Rakyat.PT. Refika Aditama, Bandung.

Suhartono, Edy, 194. Teori Peran: Konsep, Deitasi dan Implementasinya, Graedia Pustaka Utama, Jakarta.

Sumadiningrat, 2000. Pembangunan berwawasan Lingkungan, LP3ES, Jakarta.

Sutanto, Agus.1996. Keusahawanan Dan Usaha Kecil Di Pedesaan. Jurnal Populasi Bulletin Penelitian Kebijaksanaan Kependudukan. Vol. 7 No. 2. Hal:80-90. 
Supriyatna Tjahya, 2000. Strategi Pembangunan dan Kemiskinan, PT Raneka Cipta, Jakarta.

Swasono, SE. Nasution, Z. Munir R dan Madjid. 1986. Studi Kebijakan Pengembangan Sektor Informal Pusat Pengembangan Pranata Pembangunan. UI, Jakarta.

Syamsi,I. 1986. Pokok-pokok Kebijakasanaan Perencanaan Pemprograman Tingat Nasional dan Regional. PT Rajawali, Jakarta.

Thoha, Miftah, 1995. Kepemimpinan dalam Manajemen. Raja Grafindo Persada, Jakarta.

Todaro, Michael P., 1983. Pembangunan Ekonomi di Dunia Ketiga, Ghalia Indonesia.

1990. Pembangunan Ekonomi di Dunia Ketiga, PT. Erlangga, Bandung.

Usman, Sunyanto, 1990. Elit Dalam Perspektif Sosiologi.Fisip UGM, Jakarta.

2008. Pembangunan dan Pemberdayaan Masyarakat, Pustaka Pelajar, Yogyakarta.

Yin, R.. K. 2000. Studi Kasus: Desain dan Metode. PT. Raja Grafindo Persada, Jakarta. 
